\title{
The In-Class Flip Model In Teaching Speaking: Improving Elementary Students' Skill And Learning Process
}

\author{
Adin Fauzi ${ }^{1}$ \\ ${ }^{1}$ Primary School Teacher Education, Universitas Islam Balitar, Blitar \\ e-mail: adinfauzi2693@gmail.com
}

\begin{abstract}
This study aimed to enhance the students' speaking skill and the learning process of speaking by implementing the in-class flip model. The participants of this classroom action research were grade $V$ students of an Islamic elementary school. There were six students who participated in this study. This study was conducted in one cycle consisting of two meetings. The data were collected through observation, interview, and rubric. The findings indicate that the students' speaking skill improve after learning in the in-class flip model. Before this study, the students struggled with speaking. At the end of this study, the students perform better in speaking in the aspects of vocabulary, pronunciation, and structure. The learning process is student-centered thanks to group activities. The students are also more active, motivated, responsible, and cooperative during the learning process. This study concludes that the in-class flip model is effective to teach English to young learners.
\end{abstract}

Keywords: Speaking; Learning Process; The In-Class Flip

\section{Introduction}

Teaching English at primary schools has never been straightforward. English teachers at primary school encounter some typical challenges such as cognitive development, motivation, attention, multilevel groups, and assessment (Nunan, 2010). Dealing with classroom context, Ho (2003) said that English teachers in East Asia countries were reported having insufficient time to teach English during a week. As a result, they had little chance to conduct student-centered teaching. The similar case was found in the present study figuring out that the English teacher only had 90 minutes per week - even less - to teach English. What is more, it is reported that primary school students, notably those who lived in rural areas, were lack of motivation and interest in learning English since they did not see the real purpose of English in daily life owing to their little interaction with foreigners ( $\mathrm{Li}, 1998$; Ho, 2003). This finding is similar to the case of the present study discovering that the majority of students being studied were less motivated and having little interest in learning English.

In Indonesian context, English teachers are reportedly faced with some problems. One of the biggest challenge is the status of English subject as local content, which affect the availability of teaching resources (Rahayu, 2016). Since English belongs to local content at primary school in Indonesia, hardly any schools have varied resources for students (Faridi, 2010). This challenge was apparent in the present study; that is, the English teacher still adopted a single workbook on a daily basis. This problem can actually be solved by using technology, which provides abundant resources for teachers and students.

Dealing with the use of technology, today's teachers can maximize the Internet to mingle online learning with face-to-face learning theoretically known as blended learning. Flipped classroom - a type of blended learning - was then introduced and this model is applicable in teaching English at primary school, as suggested by Anwar \& Pratama (2016), and Anwar (2017). Flipped classroom is actually not a bizarre model since its nature is quite similar to blended learning; that is, the idea to integrate virtual and face-to-face meeting. This model is viewed effective to date since it allows students to learn concepts deeper, as well as brings technology into the learning process. Flipped classroom was firstly implemented by Bergmann \& Sams - the pioneers of flipped classroom - in 2007 (Bergmann \& Sams, 2014). After its introduction, several studies have provided adequate evidences that flipped classroom is promising in language learning in diverse educational levels (Webb, Doman, \& Pusey, 2014); Evseeva \& Solozhenko, 2015; Soliman, 2016; and Chilingaryan \& Zvereva, 2017; Prabawanti, Sumardi, Supriyadi, \& Fauzi, 2019; Fauzi, 2019). 
Although flipped classroom has been largely studied, little has been written regarding what is known as the in-class flip (Gonzalez, 2014). It is a modification of flipped classroom traditional, in which teachers do the "flip" in the classroom. This version is suitable for teachers who teach in rural areas, especially when they have no control over stable Internet access, availability of tools, and technology literacy of each student at home. In addition, the flip version is potentially able to boost students' motivation and interest in learning English since there is a lot of engaging activities involving technology in the classroom. Teachers can also gain benefits from the in-class flip since they can observe students' learning behavior (Gonzalez, 2014).

This action research is expectantly able to solve the problems found in speaking class of grade $V$ students. From the preliminary study, it was found that the students had troubles in speaking in terms of pronunciation, vocabulary, and structure. One of the topics that they were struggling with was daily activities. This classroom action research was thus conducted to improve the students' speaking skill as well as to augment the learning process of speaking. It is believed that through a series of engaging learning activities and adoption of technology, the students' speaking skill could be improved, and the traditional learning process would be transformed. They could learn speaking meaningfully and enjoyably through varied practices. What is more, the teacher would be more creative in designing learning process.

\section{Method}

The suitable method for this study was classroom action research. This kind of research method is typically adopted to understand the teachers' problems, and subsequently solve the problems in a planned, systematic, and cyclical study (Ary, Jacobs, Sorensen, \& Razavieh, 2010; Creswell, 2012). According to Carr \& Kemmis (1986, as cited in Kemmis, McTaggart, \& Nixon, 2014) classroom action research belongs to technical action research. Technical action research is guided by an interest in improving control over outcomes. In doing technical action research, researchers aim to control and improve the outcomes of their practices (Kemmis, McTaggart, \& Nixon, 2014). In the present study, the researcher aimed to improve the students' speaking skill and augment the learning process of speaking.

This study was conducted in a series of steps typically called action research spiral. Steps in the spiral include planning a change, acting and observing the process and consequences of the change, reflecting on these processes and consequences, and then replanning, acting and observing, and reflecting, if necessary (Kemmis, McTaggart, \& Nixon, 2014).

This study embraced the students of grade $\mathrm{V}$ at an Islamic elementary school as the participants. The data were collected through several techniques. Based on the teacher's observation prior to this research, the students were found struggling with speaking. After identifying the problems, the teacher-researcher designed a lesson plan using the in-class flip idea. Once the lesson plan had been designed, the researcher implemented the in-class flip model. During the learning process, the researcher observed the learning process by using observational checklist. When the learning process was over, the researcher interviewed some students to figure out their opinions regarding their speaking improvement and learning activities.

The series of steps above were included in one cycle, in which there were two meetings in each cycle. At the end of the cycle, the researcher assessed the students' speaking skill. When it comes to reflecting, the researcher analyzed the speaking rubric, observational checklist, and interview result. If the students' speaking skill improved, and the learning process turned out to be student-centered, the cycle was said to be successful.

Actually, this research would take place at school. However, due to Covid-19 pandemic, it was impossible to carry out this research in the classroom. Moreover, since the majority of students come from different areas (village), the researcher was unable to involve all the students (21) in this research. Therefore, the researcher decided to randomly select 6 
students who live nearby the researcher's residence. This was considered as the best option for the researcher to continue conducting this research.

\section{Findings and Discussion}

This research, which was partly conducted during school temporary closure, yielded meaningful findings regarding the implementation of the in-class flip model to improve the students' speaking skill and learning process of speaking. In this study, the students were intensively trained to speak English, particularly in daily activities topic. There were three main activities set by the teacher in the in-class flip: watching videos, vocabulary and pronunciation practices, and structure practices. The six students participating in this study were divided into two groups. Each group was firstly assigned to come to the first station, namely video station. In this station, each group watched a video explaining about vocabulary, pronunciation, and expressions regarding daily activities topic. While watching, they took notes and asked some questions. In this situation, the teacher helped explain the material and answered the students' questions. Figure 1 depicts the situation when the students watched the video.

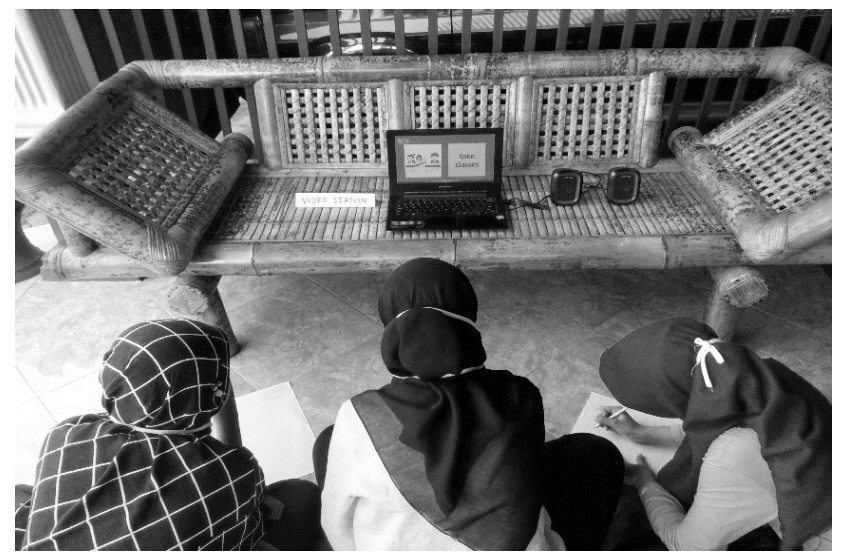

Figure 1. The students watched the video in the first meeting

The outcome of this activity was the students' preliminary understanding of vocabulary, pronunciation, and structure of daily activities expressions. Then, the students moved to the next station namely vocabulary and pronunciation practices. In this station, the students played a web-based game adopted from British Council. The students played a matching game, that is, they matched daily activities vocabulary with pictures. This way, the students learned the meaning of vocabulary more straightforwardly and enjoyably. After that, they studied how to pronounce those vocabulary through the sound feature provided in the game. With the help of the teacher, the students practiced pronouncing each vocabulary. Figure 2 shows the situation when the students learned vocabulary and pronunciation.

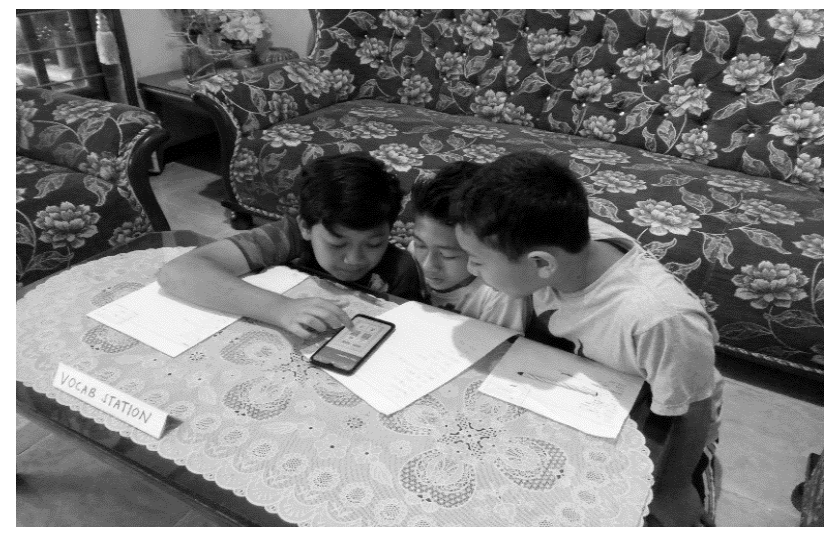

Figure 2. The students learned vocabulary and pronunciation 
To make learning more fun, the teacher asked the students to play a mime game. In this game, the students had to act out daily activities vocabulary. When a member of the group acted out daily activities vocabulary, other members made a guess and said the vocabulary loudly. The teacher's role in this station was to help them when they had problems either in understanding the meaning of vocabulary or pronouncing the vocabulary. The teacher also corrected the students' mistakes in pronouncing the vocabulary. This is to make the students able to speak correctly. Most importantly, the teacher maintained the students' motivation by providing positive feedback.

After learning vocabulary and pronunciation, the students moved to the next station namely structure station. In this station, the students learned how to make correct sentences in expressing daily activities. A web-based game adopted from British Council was also adopted to make students more interested in doing the practice. There were two games with different difficulty level. The first game only focused on arranging simple jumbled sentences. There were three or four words that the students must arrange in that game. Once they finished arranging one sentence, they had to write it down in their book. After all the sentences were completed, the teacher drilled the students in saying the sentences. The second game was a bit more difficult in which there are some sentences with missing words. The students must fill in the blank with the correct vocabulary. The challenge was that the structure of the sentences was more complex. In this case, the teacher guided the students in understanding the sentences. Figure 3 depicts the situation when the students learned structure.

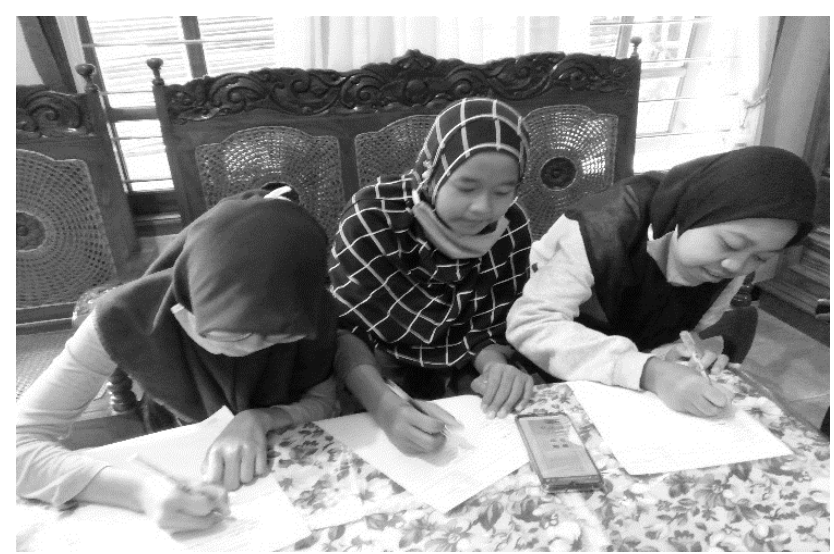

Figure 3. The students learned sentence structure

After the students completed all the three stations, the teacher reviewed the lesson. Some positive indications were that the students looked contented and relaxed during the learning process. They enjoyed playing game and doing the practices with low level of shyness. Moreover, the students seemed confident when they worked in group. The researcher then tried to sustain those positive things in the second meeting.

The second meeting was carried out a week after the first meeting. The focus of the second meeting was to progress the students' knowledge and skill. The activities in the second meeting were simpler than the first meeting. In the second meeting, the teacher played a different video. The video was about daily activities of two kids asking asked each other about what they do regularly. This video was adopted to show students how to express their daily activities naturally and fluently. Figure 4 illustrates the situation when the students watched the video. 


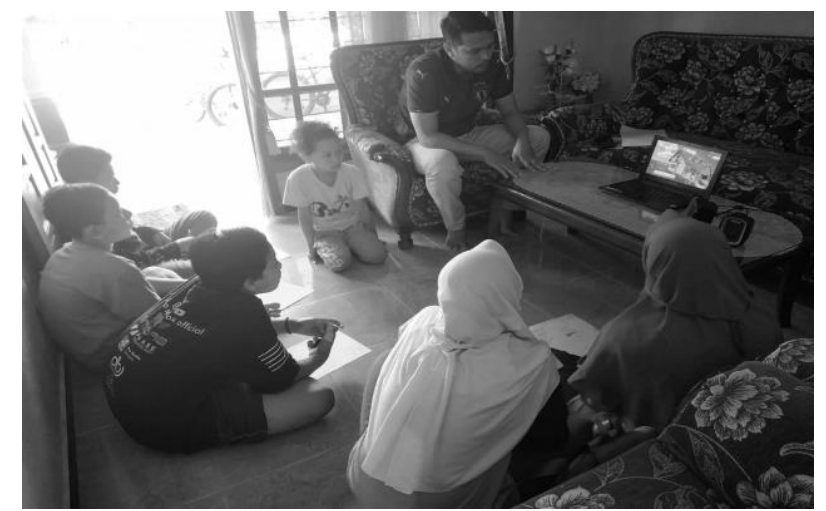

Figure 4. The students watched the video in the second meeting

During the video playing, the teacher paused the video when there were several expressions that should be explained. Then, the students were asked to repeat the expressions. This way, the students learned vocabulary, pronunciation, and structure at a time. After watching the video and learning daily activities expressions from the video, the students must practice telling their daily activities. Prior to practice, the students could arrange what they were going to tell. The teacher helped the students to arrange the correct sentences. Although accuracy of sentence is not the main concern in this study, but it remains an integral part in one's speaking to be easily understood by others. Therefore, the teacher guided the students in creating good sentences. The goal was to make them accustomed to using language correctly.

When the students were ready with their preparation, they had to tell their daily activities orally. The type of speaking assessment was individual speaking. Each student performed one by one in front of the teacher and their friends. The focuses of speaking assessment were vocabulary, pronunciation, and structure. The result of speaking assessment was satisfactory. Each student performed well. Their vocabulary were varied; their pronunciation was adequately good; and their sentence structure was fairly accurate. In addition, the students' self-confidence was excellent. All these positive results are gained from the modelling process which covers all the components of speaking such as vocabulary, pronunciation, and sentence structure.

All these findings provide enough evidence that the students' speaking skill significantly improved after doing all practices in the in-class flip model. Before implementing the in-class flip, the students' major problems in speaking were limited vocabulary, incorrect pronunciation, and inaccurate sentence structure. The majority of students were also shy when they performed. Besides, they did not enjoy the learning process since they just learned to speak by using course book. After they participated in the in-class flip model, they showed significant improvement in their speaking skill and self-confidence, and the learning process turned out to be enjoyable and student-centered as well. Therefore, the first cycle, which consisted of two meetings, was successful.

Before the cycle was ended, the teacher conducted a reflection with the students. The aim of this activity was to discuss the students' progress and challenges during the learning process. When the students were performing, the teacher videoed them. Then, their recorded performances were played after all the sessions done. During the video playing, the students looked at their improvement and mistakes. If there were some mistakes, the teacher paused the video, and corrected the mistakes. Most importantly, the teacher praised all the students for their performances. At the end, the teacher interviewed the students to obtain their opinions regarding the learning process in the in-class flip, as well as their progress after participating in this research.

When asked about the value of the in-class flip, the students said that the model was effective to learn English. Compared to learning with course book, they preferred learning with videos, games, and physical activities included in the model. They enjoyed learning 
concepts through videos. They say, "Learning through videos is more interesting." In addition, they generally said that audiovisual helped them more understand the concepts.

Another aspect that makes the in-class flip model more effective is the adoption of web-based games. The students had no difficulties in playing the game since they are well acquainted with smartphone and games. One of the students say, "Learning while playing is interesting. It does not make us bored." This finding confirms the result of observation showing that the students were enthusiastic about the game. Each group worked together to finish the game.

In addition to the instructional media, a crucial aspect in the in-class flip is teacher guidance. In this model, the teacher's role is to go around the stations to help students whenever they need assistance. In the video station, for example, the students firstly learned concepts from the video, and then the teacher answered the students' questions as well as clarified the concepts. In other stations, the students also felt secure since if they had questions, they could directly ask the teacher. Regarding these teacher's roles, the students revealed that teacher guidance is fundamental in learning process. They further say, "If there is no teacher, we cannot learn well." This finding is an evidence that teacher is irreplaceable in learning process, and one of the instructional models that maximizes the teacher's roles is the in-class flip.

Dealing with the students' improvement, they revealed that learning activities in the inclass flip improve their speaking skill. In addition, the existence of teacher as the facilitator also boosted their self-confidence. The students clarified that they experienced much progress with their speaking skill. After following all the processes, one of the students say, "I know more vocabulary, pronounce well, make sentences, and speak." This finding is a clear evidence that the in-class flip is a suitable model to teach English to young learners.

Based on the findings presented above, there are some critical points that is worth discussing. To begin with, the in-class flip was found beneficial to improve learning process, which appeared to be more student-centered. The students learned in groups, and the teacher became the facilitator. In this context, the students can get help whenever they face difficulties in learning (Bergmann \& Sams, 2014). When students can easily ask questions to the teacher, the teacher-student interaction automatically improves.

In this study, the students were divided into groups. Then, each group learned concepts in three stations namely video, vocabulary and pronunciation, and structure stations. This student-grouping concept is similar to Clark (2015) who also grouped his students in conducting flipped classroom. Group activities surely creates an atmosphere of learning (Bergmann \& Sams, 2014). In this case, students begin to be more responsible for their own learning and they are no longer passive in learning process. The finding of this study thus supports Clark (2015) regarding the implementation of group activities as a technique to create effective learning in flipped classroom, particularly in face-to-face session.

Another point which is worth discussing in this study is the use of video in explaining the concept. Two videos adopted in this study were used as a stimulus to other activities: vocabulary, pronunciation, structure, and speaking practices. The adoption of video in this study strengthens what is said by Goldstein (2017) that video is being exploited at the start of the lesson to activate schema and engage learners. In addition, the students participating in this study said that video made learning more interesting. As a result, they were more motivated to learn. In line with this finding, Clare (2017) argues that video is one of the best forms of education. It clearly boosts the students' motivation. Through video, students can learn more quickly, intensely, and memorably. Dealing with English learning, video can provide access to English speaking culture as well (Clare, 2017).

As a final remark, the in-class flip is a solution for teachers and students who have poor Internet access impeding them to perform traditional flipped classroom. The result of survey of teacher and teacher educator needs during the Covid-19 pandemic done by British Council (2020) indicated that poor Internet connection is a real problem for teachers. With regard to this finding, teachers - in the near future - can opt to conduct the in-class flip since 
all the processes are done in the classroom; therefore, the Internet access is no longer the main issue.

\section{Conclusion and Recomendation}

This study focused on improving the students' speaking skill as well as the learning process of speaking by implementing the in-class flip model. The findings indicate that there is a considerable improvement on the students' speaking skill. This improvement is the result of focused activities namely learning concepts through videos, practicing vocabulary and pronunciation, making sentences, and speaking. The involvement of digital games also contributes to the students' improvement and motivation in learning. More importantly, the students can learn effectively since whenever they have problems, they can directly ask the teacher. This can be done thanks to the teacher's role as the facilitator of learning process in the in-class flip model. Although this study yielded positive results, the effectiveness of the inclass flip should be further confirmed by involving larger participants. In addition, future researchers can investigate the effect of the in-class flip on other English skills. Equally important, future researchers can develop a new flipped classroom model for teaching English at either primary, secondary, or higher education. Later on, when the situation is normal again and schools reopen, teachers can implement the in-class flip to create an effective, motivating, and enjoyable learning process.

\section{Acknowledgement}

The researcher would like to express his deep gratitude to Universitas Islam Balitar Blitar for funding this entire research project under the decree number 044/15/SK/UNISBA/IV/2020.

\section{References}

Anwar C., \& Pratama, A. 2016. Flipped Classroom in Teaching Speaking to Young Learners. Proceedings of the 63rd TEFLIN International Conference, Surabaya.

Anwar, C. 2017. Flipped Classroom in Teaching Vocabulary to EFL Young Learners. Proceedings of the 2nd TEYLIN International Conference, Kudus.

Ary, D., Jacobs, L. C., Sorensen, C., \& Razavieh, A. 2010. Introduction to Research in Education. Wadsworth: Cengage Learning.

Bergman, J., \& Sams, A. 2014. The Flipped Classroom, CSE, 17(3), 24-27.

British Council. 2020. A Survey of Teacher and Teacher Educator Needs during the Covid-19 Pandemic. Retrieved from https://www.teachingenglish.org.uk/sites/teacheng/files/covid19-teacher-teachereducator-survey.pdf?utm_source=facebook-bcteachingenglish\&utm_medium=socialmanaged\&utm_campaign=bc-teachingenglish

Chilingaryan, K., \& Zvereva, E. 2016. Methodology of Flipped Classroom as a Learning Technology in Foreign Language Teaching. Procedia - Social and Behavioral Science, 237(2017), 1500-1504.

Clare, A. 2017. The Power of Video. In K. Donaghi, \& D. Xerri (Eds.), The Image in English Language Teaching (pp. 33-42). ELT Council.

Clark, K. R. 2015. The Effects of the Flipped Model of Instruction on Student Engagement and Performance in the Secondary Mathematics Classroom. Journal of Educators Online, 12(1), 91-115.

Creswell, J. W. 2012. Educational Research: Planning, Conducting, and Evaluating Quantitative and Qualitative Research. Boston: Pearson Education.

Evseeva, A., \& Solozhenko, A. 2015. Use of Flipped Classroom Technology in Language Learning. Procedia - Social and Behavioral Science, 206(2015), 205 - 209.

Faridi, A. 2010. The Development of Context-based English Learning Resources for Elementary Schools in Central Java. Excellence in Higher Education, 1(1), 23-30.

Fauzi, A. 2019. Redefining Learning Process through Flipped Classroom. Konstruktivisme: Jurnal Pendidikan dan Pembelajaran, 11(2), 114-122. 
Goldstein, B. 2017. A History of Video in ELT. In K. Donaghi, \& D. Xerri (Eds.), The Image in English Language Teaching (pp. 23-32). ELT Council.

Gonzalez, J. 2014. Modifying the Flipped Classroom: The In-Class Version. Retrieved from https://www.edutopia.org/blog/flipped-classroom-in-class-version-jennifer-gonzalez

Ho, W. K. 2003. English Language Teaching in Asia Today: An Overview. In W. K. Ho and R. Y. L. Wong (Eds.), English Language Teaching in East Asia Today: Changing Policies and Practices (pp. 1-32). Singapore: Eastern Universities Press.

Kemmis, S., McTaggart, R., \& Nixon, R. 2014. The Action Research Planner: Doing Critical Participatory Action Research. Singapore: Springer Science + Business Media.

$\mathrm{Li}$, D. F. 1998. 'It's Always More Difficult than You Plan and Imagine': Teachers' Perceived Difficulties in Introducing the Communicative Approach in South Korea. TESOL Quarterly, 32(4), 677-703.

Nunan, D. 2010. Teaching English to Young Learners. Anaheim: Anaheim University Press.

Prabawanti, F. E., Sumardi, Supriyadi, S., \& Fauzi, A. 2019. Teaching Strategies in EFL Flipped Classroom. A Trend towards Education 4.0. In the $2^{\text {nd }}$ International Conference on Language, Literature, and Teaching (pp. 47-54). Muhammadiyah University of Surakarta. Retrieved from http://hdl.handle.net/11617/11137

Rahayu, V. W. T. 2016. Teachers' Challenges in Teaching English to Young Learners in Rural Public Primary Schools in Salatiga (Undergraduate thesis, Christian University of Satya Wacana Salatiga, Indonesia). Retrieved from https://repository.uksw.edu/bitstream/123456789/9473/2/T1_112012033_Full\%20text .pdf

Soliman, N, A. 2016. Teaching English for Academic Purposes via the Flipped Learning Approach. Procedia - Social and Behavioral Science, 232(2016), 122-129.

Webb, M., Doman, E., \& Pusey, K. 2014. Flipping a Chinese University EFL Course: What Students and Teachers Think of the Model. The Journal of ASIA TEFL, 11(4), 53-87. 